\title{
Are words signs or symbols?
}

\section{Mubasher Mehdi}

\author{
M.Phil (English), Assistant Professor of English, Govt. Emerson College Multan, Punjab, Pakistan
}

\begin{abstract}
This is not the debate of today. But language today is playing multiple roles. This is significant to talk now about the words. The structuralist, the formalist and existentialist approaches towards words should be seen. This very article looks at the different attitudes towards words and is based on Sartre's remarkable book "What is Literature",
\end{abstract}

Keywords - Sign, Symbol, Object, Image.

\section{INTRODUCTION}

The problem is of differentiation and generalization. The very specificity towards things has developed differentiation. But definitely, things are integrated and interconnected. There is a quest now to, first isolate the different things, and all of them, and then see them as a whole. Modern linguistics is distributing the language in to chunks and dividing them as well. To see language in bits and chunks like; verbs, lexis, and others, has brought the linguists to structuralist approach. The language is structure and how it exhibits the hidden treasure of man, which has also embodied his heritage, and has become the object of the greatest debate today. Is to reveal language is to reveal man himself? Can the word make him to be?

\section{LANGUAGE THEORIES}

The appealing are behaviouristic and innate language learning theories. Behaviorists say that language is a conditioned act. According to Chomsky, language is inside but there is assumption that speech is primary. The system related to language operation, both in speech and writing, acts at same time in mind. When you think, you don't appear but identify the words in mind. This process is not of speech but of thought. But even in brain when you are thinking and identifying the words, they are either in image or you are penning them down in your mind or words are reflected. Speech comes after thinking, not immediately.

\section{STRUCTURALIST VIEW ABOUT LANGUAGE}

The structuralist view about language is to distribute it in chunks. These chunks show the nature of discourse. But when discourse is seen in isolated chunks, different things are seen in isolated chunks, and different things are depicted. Verbs remain verbs and adjuncts, determiners, then need to be identified and they all reflect their own sole properties. Therefore, language theory moved to post-structuralism in twentieth century. Even Jacques derrida talked about differentiation of polarities. He was of the view to destroy polarities, but he also thought speech is primary, and in order to explain a discourse, infinite serialization is required. Moreover, he talked about presence which is inherent in absence. But there are certain things which are felt as well. Even if absence gives realization of presence, then that means there is something between them which is referring presence in absence.

\section{FORMALIST SCHOOL'S ATTITUDE}

The formalist school has a different view. The formalists of twentieth century emphasized the importance of form. The form of a poem is of a value, not its contents. But the form is important because it is constructed on structures. Many structures combine to make a form or shape or a pattern. But, if pattern is even complex, even then square shape or rectangular shape again refer something. Any pattern or form may not only be beautiful but has in it an abstraction. And, that very abstraction is also substantiated. To simplify this logic, it could be said that form and structure is apparent or visual, that which it refers is abstract, but that very imaginative - abstraction is again concrete in the form of words, music, painting and dance. But, the words even if refer, they refer above, and that beyond, is a different dimension. That beyond may be dislocated, but visualized in mind. In a supposition we can say it could be in a form of feelings. And even the feelings are also logical thought correlated structures, but they could not be divided because they are immeasurable and uncontrollable. These feelings generate vision.

\section{SARTRE'S VIEWS ABOUT WORDS}

Jean Paul Sartre (2006:6) discusses this feeling abstraction idea in this way, "the man who talks is beyond word and near the object, whereas the poet is on this side of them. For the former, they are domesticated, for the latter they are in the wild state. For the former, they are useful conventions, tools which gradually wear out and which one throws away when they are no longer 
serviceable; for the latter, they are natural things which sprout naturally upon the earth like grass and trees."

Sartre has made a differentiation. First, he said that common talking man thinks about the words as object. If, words are objects then words are pleasant and satiristic. And satiristic jokes and pleasant talks are interpreted in different way. And that very impact develops reaction of pleasure, hatred, revenge and reaction of reacting. All these things are immaterial but have forms, as they in themselves are structures. There is also the pleasure of the person who throws words. This means words may refer but that very thing, which is not in conventional shape is concrete.

The last part of Sartre's view in quotation refers to image formation of words. It is also a two way thing. The impression and imprint are never disjointed. How it happens is a complex process? The brain reads the impression, and after words are identified and then again are exhibited in the form of words, but before converting in words it is thoughtfully identified. That identified image after constant reflection in a specific shape is emitted again as a word or name.

Taking the specific example of the poet's use of the words, Sartre (2006:7) reflects, "not knowing how to use them as a sign of an aspect of the world, he sees in the word the image of those aspects. And the verbal image he chooses for its resemblance to the willow tree or the ash tree is not necessarily the word which we use to designate these objects. As he is already on the outside, he considers words as a trap to catch a fleeing reality rather than as indicators which throw him out of himself into the midst of things. In short, all language is for him the mirror of the world."

Sartre has talked four things. One is that the use of words or words is part of a giant reality. Secondly, he distinguishes the poetic imagination, that the word for poet is a reflection of the world. Thirdly, he symbolizes. The example given by sartre is: willow as a word used by poet may not mean that. Fourthly, he is of the view that poet tries to comprehend the imaginary. We can say that physical reality in the form of nature is gigantic. But in that physical reality man is now not nominal. The words are expression of that reality. They are not mirror of the world.

You can't name and identify everything. Modern man has also created many tools. These tools are the innovation or incarnation of his mind. This has occurred due to constant exploration, though there is still room for him. He has named different natural objects. But, how has he named those created by him? It means there are properties of the elements which have been named and identified. And these properties refer that there are several things, whether they may be utilized or not. Or even there is still hidden a lot.

When we become dumb by a scene, definitely it means silence has overwhelmed. And, silence is always a hidden speech. As written words may be symbols or signs, they may be images or objects, but word is an expression of the immeasurable.

In mind vocabulary is infinite. An idea suggested by Chomsky. The idea is simply that apparent depicts deep and then deep becomes apparent. But, one thing is clear from Sartre's view that it is just one aspect. The word may be significant as Sartre says, but, definitely speech is related to silence. The silence creates speech as mentioned above through a complex process. But, as Chomsky says vocabulary is infinite. Same is the case, because Sartre perceives that word is a part of bigger reality, so it could be thought, that mind may also has several ways. As, word depicts single reality whether sign or symbol, mind may be the greatest faculty.

\section{CONCLUSION}

Sartre (2006:9) further says, "the poet is absent. And the question involves no answer, or rather is its own answer". Same is the case of silence, and speech. The answer of silence is speech. And word explains that speech. There are certain things beyond silence. There are certain things beyond speech. And there are many things beyond even word. Beyond speech may be silence, as explained, beyond silence may be speech, as by Sartre, beyond word may be symbol or sign or signified. But, all of these things refer abstraction - identified objects or structures, having a form that is substantial in the realm of imagination. As Sartre (2006:10) reflects, "the interrogation has become a thing as the anguish of Tintorretto became a yellow sky. It is no longer a meaning but a substance."

\section{REFERENCES}

[1] Sartre, Jean-Paul (2006) What is Literature, Routledge Classics.

[2] Ibid 